Rupkatha Journal on Interdisciplinary Studies in Humanities (ISSN 0975-2935), Vol. 10, No. 1, 2018 Special Issue on "Interrogating Cultural Translation: Literature and Fine Arts in Translation and Adaptation" In collaboration with the Department of English, Amrita Vishwa Vidyapeetham Guest-edited by Dr. Hari M G, Amrita Vishwa Vidyapeetham, Coimbatore, India

DOI: https://dx.doi.org/10.21659/rupkatha.v10n1.09

Full Text: http://rupkatha.com/V10/n1/v10n109.pdf

\title{
Mapping the contours of a Tempestuous Interiority: Reading Kamala Das through Kristeva
}

\author{
Sandhya $\mathrm{V}^{1}$, Hari $\mathrm{M} \mathrm{G}^{2}$ \& Harini Jayarman ${ }^{3}$ \\ ${ }^{1}$ Assistant Professor, Department of English and Humanities, Amrita Vishwa \\ Vidyapeetham, Coimbatore, India. Email:v_sandhya@cb.amrita.edu ORCID Id: oooo-oooz- \\ 8885-3571 \\ ${ }^{2}$ Assistant Professor, Department of English and Humanities, Amrita Vishwa \\ Vidyapeetham, Coimbatore, India. Email:mg_hari@cb.amrita.edu ORCID Id: oooo-ooo3- \\ 0508-8112 \\ ${ }^{3}$ Professor, Department of English and Humanities, Amrita Vishwa Vidyapeetham, \\ Coimbatore, India. Email:j_harini@cb.amrita.edu ORCID Id:0ooo-0oo2-9747-2850 \\ Received September 27, 2017; Revised December 11, 2017; Accepted December 30, 2017; Published February o4, 2018.
}

\begin{abstract}
This paper examines Kamala Das' attempt to translate the ever changing contours of feminine subjectivity into the structured space of language, in the light of the French philosopher Julia Kristeva's theorization of psyche. Das' instinctual urge to resist definitive structuring of the inner zones of female consciousness echoes Kristeva's concept of Revolt, which is identified to be the psychic re-ordering to explore the varied dimensions of subjectivity. Revolt is explained by Kristeva as the disruptive potential of the innate desire drives of human psyche, which challenge the very stability of the discourses pertaining to identity in the 'Symbolic'. The manifestation of Revolt in the writings of Das breaks the fetters of gendered identity and opens up the possibilities to experience one's 'self in unspecified ways. The resistance to the order of the 'symbolic' and the inclination to oscillate between the blurring borders separating the most natural urges of the "semiotic" and the ordered space of the symbolic, defines the essence of female psyche in Das. This paper discusses this unstable and trangressive nature of female subjectivity in Das which reflects Kristeva's thrust on the dynamics of Revolt in defying categorization.
\end{abstract}

Keywords: Kamala Das, Kristeva, Revolt, Subjectivity

\section{Introduction}

Literary works which touch upon the profound dimensions of human predicament have a universal quality which invariably evokes the thoughts of other writers and philosophers who have engaged with life intensely. Meaningful correlations between literature and philosophy come into being through such explorations of the same terrain. This paper is about one such correlation - the overlapping spaces in the creativity of the Indian writer Kamala Das and the Philosophy of

(C) Authors. Published by AesthetixMS under a Creative Commons Attribution Non-Commercial 4.0 International License (http://creativecommons.org/licenses/by-nc/4.0/). 
the French theorist, Julia Kristeva. It is quite fascinating to see the way Kamala Das's works become literary expressions of some of the concepts introduced by Kristeva. The thrust that Kristeva gives to the disruptive potential of the inner urges and the revolutionary possibilities that it holds for the 'speaking beings' make her a radical philosopher of our times. Das's penchant in finding an idiom to articulate the ironies of feminine subjectivity has a lot in common with the radical philosophical concepts of Kristeva.

The hallmark of Julia Kristeva's thought is its uncanny inclination towards blurring boundaries and debunking binaries. It is quite interesting that this element of daring transgression is an undercurrent in her works right from the beginning of her intellectual life. Articulating the essential nature of this transgression, she introduced a term to refer to this train of transgression - Revolt. The element of transgression Kristeva upholds and to some extent celebrates is for her an act of giving vent to the semiotic dimension of human psyche and thereby being in tune to the maternal chora. A complete submission to the symbolic which has become the norm of the day would result in the creation of a mechanical way of life. Hence Kristeva stands for a creative use of the semiotic urges which would lead to pushing the boundaries of one's perception. In all her critical notions, we can discern the spirit of Revolt as an underpinning. The theorization of gender is no exception. Kristeva identifies the vibrant and lingering presence of the highly dynamic play of drives as 'chora' and she posits it as the operating principle of the human mind; and she essentially inscribes 'Revolt' in its basic functioning.

\section{2. chora}

Chora, the secret and vibrant 'inner garden', the inexpressive completeness, the ever-throbbing space of psychic energy and the charismatic realm of perpetual impulses, effortlessly finds its way into the poetic expressions of Kamala Das. Interestingly, Das' poetic language becomes a translation of a perpetual conflict between the chora and the mechanics of signification - the symbolic. This conflict is one of the defining characteristics of revolt, for Kristeva. Revolt is seen as the hallmark of a 'life of conscience': “... when it attempts to remain faithful to its internal logic. A synonym of dignity, revolt is our mysticism" (Kristeva, 2014, New Forms of Revolt, p.3), states Kristeva. Revolt is not realized as an event in the external world, but as a revolutionary quality that is innate to human mind which invariably manifests in language. Acutely aware of the infinite possibilities of a "differently constituted structure of poetry" (Harris, 2011, p. xii) Das translates the intense instinctual vibes into it.

To Das, chora is an existence which is 'away from being anybody, away from the clumsy noise and endless movement'; it is “...the soul's mute/ Arena,/ That silent sleep inside your sleep” (Das, 2014, p.47). Das identifies chora as the awareness that, only the journey inward brings in the experience of the raw inner self. The eminent critic K Satchidanandan notes in the Preface to Das' autobiography My Story titled "Relocating My Story" (2009) that "She (Das) realized later that one's real world is not what is outside one. 'It is the immeasurable world inside him that is real. Only the one who has decided to travel inwards will realize that his route has no end' -" (p.xvi-

xvii). Das beautifully poeticizes this travel to reach the inner most space of the psyche in "The Circus":

Dig into the nest of tap-roots

To unbury the revelations

Travel inwards devouring Time 
Burrowing into the myriad layers

Of the planet's body

Beyond the skin

Beyond the bones and the marrow

To the nadir of life

The hot, dark cellar

Of loneliness. (2014, Selected Poems, p.180)

In Das, the dynamic inconsistencies of the innermost desire drives offer the endless possibilities of sensible freedom. Hence, this dynamic space of 'intense emotions, speech and a rich, full complexity of life' (King, 2001, p.147) stimulates Das to take up different attitudes towards intense emotional situations, essentially initiating the much needed revolt against the consistency of emotions in the symbolic world. In "Summer in Calcutta", Das talks about the shifting, flexible and ever changing contours of the emotion called 'love' authenticating the free play of emotional thrusts in her mind. She brings out the delicate boundary which separates the love which overflows with devotional intensity and the love which changes its nature every now and then with shifting impulses and emotions in the psyche. She delightfully muses on how easy it is to passionately long for her man and to indifferently discard his presence at the same time with equally powerful intensity. The psychic realm of chora vibrates with the dizziness of perceptions when she says how drunk she is with the summer of Calcutta, and wonders how brief the unsettling emotions are. She playfully asks for forgiveness and exclaims at her ability to have an absurd intermingling of desire and brief admiration, to give birth to the many-sided emotions. Aptly echoing the observation of K Satchidanandan in "Relocating My Story" (2009) that "She (Das) transcends ready-made philosophical systems by being honest to the momentary states of her consciousness" (p.14); Das says:

“...Dear, forgive

This Moment's lull in

Wanting you, the blur

In memory. How

Brief the term of my

Devotion, how brief

Your reign when I with

Glass in hand, drink, drink,

And drink again this

Juice of April suns. (2014, Selected Poems, p.26)

\section{Significance of Revolt in Das.}

In Das, the presence of an unborn, inner psychic space manages the imbalances at the border of the psyche where the symbolic and semiotic meet. The abstract yet thoroughly analyzed perception of one's own inner self is compellingly portrayed by Das in "Feline". Though Revolt creates constant conflict and struggles in the inner psyche, it also leads to the boundless joy of experiencing and being the original and shattered inner depths of an individual, where the most innate drives are at play. Das acknowledges this very fact and she highlights the futility of existence and hollowness of self-identification with the sanctioned roles in the symbolic world which are devoid of the spirit of enquiry into the inner self. One who fails to transcend the limits by sticking on to the designed pattern of existence, fails to live authentically and life becomes just a 'show' bereft of perceptional depth and dimension. Agonized, Das says in "Feline": 
...We weave the fabric

Of our art, settling and unsettling an ancient

Design, the earth, the sun, the yellowed leaf, pain,

Illness, death and of course some inconstant love. (2014, Selected Poems, p.143)

The craving to travel beyond the mundane periphery of experiences sets Das apart as a genuine philosopher who dwells into the possibilities of intimacy with one's own self and the other. As Noelle McAfee contends, Kristeva underscores 'the importance of revolt for the experience of intimacy' (1986, p.25). Revolt as seen in some poems of Kamala Das is about longing for experiences even beyond the limitations of body. Das's poems which deal with the seamless experience of longing for a 'oneness' in relationships beyond the fetters of body are underpinned by a profound philosophical depth which borders on mysticism. In "Advice to Fellow-Swimmers", the inner-most core of one's psyche from where desires emotions, fantasies and drives spring forth - the 'chora', is seen as a pristine space of infinite possibilities:

Go swim in the great blue sea

Where the first tide you meet is your body,

That familiar pest,

But if you learn to cross it

You are safe, yes, beyond it you are safe,

For even sinking would make no difference then... (Das, 2014, Selected Poems, p.116)

Precisely pointing out the well-acquainted and pre-determined space of the symbolic, Das acknowledges the impossibility of any kind of transformation in this definitive space. Das' poetic persona looks into her own self and realizes the contrast between chora, the 'modality of significance' (Kristeva, 1984, Revolution in Poetic Language, p. 94) and the symbolic order. She is acutely aware of the subversive potential of this intimate psychic space to challenge the ordered discourses. At the same time, she is confused and threatened by the very presence of the vibrant anarchy that she can sense inside. In "Feline" she says:

...There is a sea wailing beneath the sea,

A sky behind the taut drapes of our firmament,

A rain that rains hard and long within the summer-rain.

Another lives in me, I fear, a twin left unborn,

Unnamed, unacknowledged, bitter with defeat,

And, she with her new-moon eyes stabs my face

And turns me so often, half human, half feline. (2014, Selected Poems, p.143)

Moving beyond the shackles of structured discourse, Das talks about the need to find the meanings from within. When the mind is ready to striptease, the journey within unveils the roots of one's identity, desire and self-formation. As exactly pointed out by Kristeva, the dynamic possibility for Revolt springs forth only when there is a more specific, personal and intense journey from the outer to the inner representing the journeys from culture to nature, from body to mind, from conscious to unconscious; nurturing and establishing the specificity of existence even while being a part of the larger community. Kristeva notes in "New Forms of Revolt":

“... there is no answer to social, historic and political impasses without a radical inner experience; an inner experience that is demanding, unique, and able to appropriate the complexity of the past in order to approach the present and the future...This inner experience is also meant to avoid the nonsensical and vengeful rejection, which is both symmetrical and powerless, that denounces one's opponent without being able to propose a sensible alternative... 
It is necessary to have men and women with inner experiences that are unique, inquisitive, and uncompromising. It is on this condition alone that they can be reformers" (2014, p.2).

Experiencing the depths of one's own inner-most self beyond the boundaries of the body through the pleasure of doubt and inquiry is highlighted when Das says in "Composition":

\author{
...by confessing \\ by peeling off my layers \\ I reach closer to the soul \\ and \\ to the bone's \\ supreme indifference. (2014, Selected Poems, p.63).
}

Keeping the urge to question alive, is identified to be the most innate and integral method of Revolt. Kristeva argues: “...questioning remains the only possible thought: it is an indication of a life that is simply living. Today, mental life knows that it will only be saved if it gives itself the time and space of revolt: to break, to remember, to re-do" (2014, p.3). The need to nurture the ever fascinating trance of a child's endless questioning urge reinforces the clarity of the concept of Revolt. Discussing the vibrant psychic space of a child, Kristeva asks in "New Forms of Revolt": "Who hasn't witnessed the pleasure trance of a child asking questions, still straddling the border between the flesh of the world and the kingdom of language? The child knows with a hallucinatory knowledge that all identity, object, person himself, the adult's response is a constructible, deconstructible chimera" (2014, p.8). The joyous experience of keeping the realm of chora intact, perfectly open for Revolt happens unconsciously and effortlessly in a child's psychic space; providing the child an easy intimacy with his/her own intimate psychic space, resulting in the utmost natural disposition of the self. This is the reason why the child is never much affected by the dictums of the symbolic world; the semiotic chora is always in an endless battle with the symbolic through the infinite possibility of questioning and experiencing the learning. The child discerns the priceless fact that self identity is a 'constructible and deconstructible chimera' without actually imbibing the immense potential of this realization. Das' poem "Nani" is a perfect example to show how the child's psychic space offers her an ever-widening horizon of endless possibilities and how the pre-meditated responses of the adult skillfully and cunningly put an abrupt end to the child's uncalculated voyage to the space of Revolt. Das' "Nani" was a pregnant maid who committed suicide in the privy of the old house years ago. The child who used to be around the maid all the time watches the spectacle of Nani hanging from the ceiling like a 'clumsy puppet' with amusement and delight, as she was doing 'a comic dance'. Years go by; the child asks her grandmother about Nani; staring at her, the grandmother asks her "Nani,... who is she?" The blunt question of the grandmother completely ends the possibility of further questioning. Das clarifies the analysis of the situation:

Each truth

Ends with a query. It is this designed

Deafness that turns mortality into

Immortality, the definite into

The soft indefinite. They are lucky

Who ask questions and move on before

The answers come, those wise ones who reside

In a blue silent zone, unscratched by doubts

For theirs is the clotted peace embedded

In life, like music in the koel's egg, 
Like the lust in blood, or like the sap in a tree... (2014, Selected Poems, p.74).

The child is anxious to discuss the past of Nani, she wants to know what happened to her, but the calculated ignorance of the outside world hushes up the possibility of further probing into an unwanted and potentially dishonorable unfairness. Das ridicules the 'contented' and 'complacent' lots for their passivity and their long lost tendency to seek answers. They lose their connection to 'chora' and fails to identify the essence of the self which lies inside, whose presence is never identified.

The essential nature of Revolt is suppressed in various ways in the Symbolic worldthrough counter questions, through baffling avoidance and rejection, through constantly reminding about and enforcing the shapes to fit in, through threatening and destabilizing the coexistence and through making the boundaries which differentiate and dictate, grow more rigid and unbreakable. The actualization of complete adherence to the rigid symbolic structures and concepts is achieved through and only through the suppression of the possibility of Revolt; the whole process appears completely natural by dulling the instinctual tendency to 'Revolt', "articulated by negation and its modalities, transgression, denial and repudiation" (Kristeva, 1982, Powers of Horror: An Essay on Abjection). As Kristeva puts it, "without the threat of revolting against the symbolic order, the psyche loses energy. Losing the life-enhancing force that chora brings to subjectivity, the self becomes more of an automation than a human being. The less the touch, the less the ability to thrive, change and live" (McAfee, 1986, p.25). "Nani" talks precisely about this lost touch with the chora, and leading the life of a mechanical being who is indifferent to his/her own self. "Nani" is a perfect example to show how the territory of Revolt is forcefully made inaccessible to the psyche by the representations of forbidden questions and inquiries.

\section{Revolt in gender identity and subjectivity}

Radical transformations in social identity, especially gender identity takes place when discourses in the symbolic are exposed to powerful disruptions in the semiotic. That dimension of subjectivity, in Kristeva's words “...exceeds the field of human capacities and limitations determined by the structure of language" (1984, Revolution in Poetic Language, 26). The subjectivity of Das' women is created and transformed simultaneously in the absolute personal space, substantiating the complete resistance of the semiotic space to systematization. As Kristeva puts it: "The semiotic chora is no more than the place where the subject is both generated and negated, the place where his unity succumbs before the process of charges and stases that produce him" (1984, Revolution in Poetic Language, p.95). The defining characteristic of Das' portrayal of women's interior spaces is nothing other than the perpetual instability of this very subjectivity. She believes that the genuine gender identity of a person can never be expressed in linguistic terms and "except in biological terms, there is hardly any difference between a man and a woman" (Kohli, 2014, p.xxxiv). Das contends that subjectivity is the essentiality of experience which lies beyond any classification. Transcending gendered identity, she asks in "The Doubt":

When a man is dead, or a woman,

We call the corpse not he

Or she but it. Does it

Not mean that we believe

That only the souls have sex and that

Sex is invisible? 
...Is she

A male who with frail hands

Clasps me to her breast, while

The silence in her sickroom, turning

Eloquent, accuses

Me of ingratitude?

And, is he female who

After love, smoothes out the bed sheets with

Finicky hands and plucks

From pillows strands of hair? (2014, Selected Poems, p.53).

In uncomplicated terms she nudges the basic questions regarding gender identity and roles associated with it; and she skillfully leaves the questions un-answered for us to probe into. Das ridicules the failure of the very basic symbolic expressions prevalently associated with gender to determine the essential nature of gender identity. The unbound thought itself proves the flexibility of gender identity, completely erasing out the signifying specificity with regard to any particular gender. The notion actualizes the prospect to have the absolute choice to fluctuate between gender roles and identities experiencing and celebrating the freedom of pure harmony and boundless liberty resulting from the sparkling Revolt in the 'inner garden'.

Similarly, in Das we can see the conscious efforts to calculatingly implant the rigid notions of sexual identity in a child's psyche which invariably lead to the unconditional acceptance of woman as her body. This is carried out in various enthralling ways as seen in Das' A Childhood in Malabar (2003). The male servant at Nalapatt makes wooden dolls for the children to play with. Little Kamala asks Kunju:

"Can't you make me a prettier doll?"

"Aren't the dolls that Kunju makes pretty?" he asked.

"They are,but..."

'A head and breasts: that's what women must have. They don't need anything else...What more do you want?" (Das, A Childhood in Malabar, p.12)

The question silences Kamala, and effortlessly it pushes her into the understanding of woman as a mere body, who doesn't need anything else to be complete. Instillation of gendered subjectivity into the psyche takes place at a very young age, closing all possible openings for thinking differently. A dynamic subjectivity which thrives on intuitive impulses decays within, in an endless attempt to fall in line with the structured patterns in the symbolic world. The perpetual requirement for exhibiting an acceptable identity, forces the individual to model or remodel himself or herself into fixed moulds to continue with the expected performance, completely avoiding innate instinctual drives. Ignoring and then forgetting the fundamental connection to the psyche wipe out the possibility of a 'psychical restructuring' (Kristeva, 1984, Revolution in Poetic Language, p.7) which is the pivotal result of Revolt, as Kristeva identifies.

The perception of self-identity, principally the identification with a particular gender seems meaningless to Das, because the binaries are established so baselessly in any given context. Identifying one's self with that of a man or a woman proves to be a futile effort, as there is always an overlapping of femininity and masculinity in one gender. The free play and overlapping of gender innateness and the 'ceaseless confrontation with the otherness' (Kristeva, 1982, Powers of Horror: An essay on abjection, p.6) break all the fixed moulds of subjectivity in the symbolic. Das believes that the limitless horizons of reachable experiences fade away as one confines himself or herself to one particular gender by adhering to all the constructed laws governing that gender in 
the symbolic discourse. In Das, the translation of the subversively anarchic space of the psyche manifests itself as the essential Revolt in the realm of gendered subjectivity. Reflections on homosexuality offer Das the possibility to defy any rule that makes one a helpless and victimized 'woman'. Homosexuality in Das often assumes the form of Revolt to extend the limits and possibilities of gender experiences; as Judith Butler notes in "The Body Politics of Julia Kristeva”, "The alleged psychosis of homosexuality, ... consists in its thorough break with the paternal law and with the grounding of the female "ego",..." (1989, p.109). In Das, homosexual relationships undoubtedly acquire the potential to claim the liberated existence of the female and Das also celebrates the much more comfortable and revitalizing experience in the intimate space of homosexuality. A clearly calculated and bold subversion of the patriarchal agenda is apparent in Das' cheerful celebration of homosexuality in her works. But being true to the ever-changing and all absorbing dynamism of her unrestrained interiority, Das never denounces heterosexual relationships, even though the latter is never perceived as the only natural and emotional sexual expression.

The recognition that sexual instincts are culturally constructed and then interpreted as innate in the most naturalistic language finds its expression in Das' uninhibited perspective towards the portrayal of homosexuality. Das talks about her 'brush with love' in My Story, remembering how strongly she was attracted to an 18 year old girl, when she was only thirteen. She talks about the joy she experienced from her physical intimacy with that girl. She views it as quite natural and much needed, since none of her relationships with men are referred to as comforting or even compassionate. She often refers to the confidence she could feel in homosexual relationships which considerably stabilized her identity as an individual. An authentic understanding of heterosexuality as "the perceptual screen provided by our (patriarchal) cultural conditioning" (Zimmerman, 1985, p.201) accounts for the much instinctual Revolt in Das in the form of lesbianism. Disfavoring the cultural construction of any kind of sexuality makes Das' attempt to Revolt, a complete and liberating process in itself. The same encompassing attitude is seen when Das talks about her husband's relationship with an older male friend too. Though paining, she takes it as the love she can never have, a love which had 'luckier takers'. She never sees or expresses it as a taboo; instead she views homosexuality as a natural choice that anybody can make to keep oneself in harmony with one's own self.

Rosemary Marangoly George’s “Calling Kamala Das Queer: Re-reading My Story” discusses how the established study of My Story gets confined to the sensationalist and melodramatic aspects of a woman's open confession and how the critics generalize and overlook the attempt of her writing to transgress the conventions of the genre of autobiography. She focuses on the 'contradictions, challenges and resolutions' that arise from the close reading of My Story, stating that "literary, critical and feminist territorial boundaries are not as clear cut as they were imagined to be" (2000, p.731). She throws considerable light on how the same sex encounters in My Story is often overlooked and rejected as the representation of her eccentric, troubled and exaggerated obsession with sex and intimate experiences. She undermines the repetitive elaborate analysis of heterosexual relationships in Das as a feeble attempt to categorize her writings as the typical protest against existing patriarchal politics. My Story is seen as a well-crafted queer text by Rosemary Marangoly George since it revolves around 'sexuality and female pleasures', sometimes exceeding the term's dimensions in queer theory by exploring beyond the sexual connotations of 'queer'. At the same time "same sex desire in the work of Das does not operate along a hetero homo divide, nor does it confer an identity as lesbian on the protagonist. Thus, even while Das consistently encodes the homoerotic into her work, she just as consistently devalues its purchase" 
(George, 2000, p.740). This very indecisiveness of Das keeps her in touch with the realm of Revolt. Das' writings express the essential nature of Revolt by constantly contradicting the possibilities.

\section{Conclusion}

Kristeva identifies Revolt as a psychic re-ordering to experience unexplored dimensions of one's subjectivity. It is never a total negation of the structured symbolic realm; it is rather an attempt to establish a sensible intimacy with the symbolic, ingraining the self unmistakably in the vivacious presence of the responsive psychic energy. As Kristeva puts it: "Through a narrative of free association and in the rejuvenating revolt with and against the old law (familial taboos, superego, ideals, Oedipal or narcissistic limits, etc.), one's singular autonomy emerges, along with one's renewed link to the other" (2014, New Forms of Revolt, p.7). In Das, this individualistic independence emanates when the awareness of the chaotic impulses grows intense and the conflict it gives rise to transform all pre-conceived notions of subjectivity. Liberating the self from identifying with any sanctioned patterns of subjectivity, Das' personae assume and parade an utterly varied gamut of roles. She never confines her identity to that of any particular type. She flutters her identity from a faithful woman to a betraying beloved, a suffering and negated wife to a vagabond, a loner to the centre of attraction, a helpless victim to a cunning schemer, a confused and pitiable child to a crooked watcher, and an unsatisfied woman to a celebrator of sensuousness. Authenticating the creatively dynamic energy drives of the inner psychic space, Das never does acknowledge her personae with any of the projections in her poetic expressions. The swift shift in subjectivity itself is the hall mark of Das' writings. She is not committed to any of the roles she plays; yet she plays each of the assumed roles with utmost authenticity and playfulness. Kristeva suggests the dynamism of the culture of the Revolt as, "The permanence of contradiction, the temporariness of reconciliation, the bringing to the fore of everything that puts the very possibility of unified meaning to the test (such as the drives, the unnamable, the feminine, destruction, psychosis, etc.): this is what the culture of revolt explores" (2014, New Forms of Revolt, p.10). Thus, anchoring onto the essential nature of Revolt, Das keeps her decisive self always in the safest bay resisting definitive subjectivity. She believes in the natural and vibrant interplay and mingling of all kinds of possibilities diminishing the border between the symbolic and the semiotic.

Kamala Das's creative world evokes the thoughts of Kristeva not because it is philosophical in tone, but for the fact that it hinges around some of the basic dimensions of human predicament that Kristeva tries to bring home in her theoretical deliberations. The creative imagination of Das that finds an uncanny idiom to capture the modes of a tempestuous subjectivity resonates in spirit with Kristeva's exposition of the dynamics between the symbolic and the semiotic, and the revolutionary quality that Revolt brings to this dyad. The translation of the urges of a volatile psyche into images created in a playful language becomes very sensible when it is placed in the framework of Kristeva's concepts.

\section{References:}

Ahmed, I. G. (2005). Kamala Das: The Poetic Pilgrimage. New Delhi: Creative Books.

Bedient, C. (1990, Summer). Kristeva and Poetry as Shattered Signification. Critical Inquiry, 16(4), 807-829. 
Brewster, A. (2010). The Freedom to Discompose: The Poetry of Kamala Das. In D. Kohli (Ed.), Kamala Das: Critical Perspectives (pp. 85-93). New Delhi : Pencraft International.

Bove, M. C. (1984, Winter). Review: The Politics of Desire in Julia Kristeva. Boundary 2, 12(2), 217-228.

Butler, J. (1989, Winter). The Body Politics of Julia Kristeva. Hypatia, 3(3), 104-118.

Das, K. (2003). A Childhood in Malabar. New Delhi: Penguin.

---. (2009). My Story. New York: Harper Collins.

---. (2014). Selected Poems. New Delhi: Penguin.

---. (2013). Wages of Love. In Suresh Kohli (Ed.) Noida: Harper Collins.

---. (2011). Old Playhouse and Other Poems. New Delhi: Orient Blackswan.

George, R. M. (200o, Autumn). Calling Kamala Das Queer: Rereading My Story. Feminist Studies, 26(3), 731763.

Harris V C. (2011). Introduction. In K. Das (Author), The Old Playhouse and Other Poems (pp. ix-xxi). New Delhi: Orient BlackSwan.

Jussawalla, A. (1970). The New Poetry. The Journal of Commonwealth Literature, 5(65), 65-78.

King, B. (2001). Modern Indian Poetry in English. Delhi: OUP.

Kohli, D. (1974). Passionate Sincerity in Indian Poetry in English. The Journal of Commonwealth Literature, 9(20), 20-34.

---. (2014). Introduction. In K. Das (Author), Selected Poems (pp. x-xciv). New Delhi: Penguin.

Kristeva, J. (2014). New Forms of Revolt. Journal of French and Francophone Philosophy, .XXII(2), 1-19.

Kristeva, J. (1984). Revolution in Poetic Language. Translated by Margaret Waller, New York: Columbia University Press.

Kristeva, J. (1986). The Kristeva Reader. Edited by Toril Moi. New York: Columbia University Press.

Kristeva, J. (1982). Powers of Horror: An Essay on Abjection. Translated by Leon S Roudiez. New York: Columbia University Press.

McAfee, N. (2004). Julia Kristeva. New York: Routledge.

Oliver, K. (1991, Summer-Autumn). Julia Kristeva's Imaginary Father and the Crisis in the Paternal Function. Diacritics, 21(2/3), 43-63.

---. (1993, Summer). Julia Kristeva’s Feminist Revolutions. Hypatia, 8(3), 94-114.

Panicker, K. A. (200o). Forword. In N V Raveendran (Author), The Aesthetics of Sensuality: A stylistic Study of the Poetry of Kamala Das (pp. iii-v). New Delhi: Atlantic Publishers and Distributers.

Patke, R. S. (2008). “Poetry since Independence”. In A. K. Mehrotra (Ed.), A Concise History of Indian Literature in English (pp. 275-310). Ranikhet: Permanent Black.

Prasad, G.J.V. (1999). Continuities in Indian English Poetry: Nation Language Form. New Delhi: Pencraft International.

Ramakrishnan, E.V. (1980). “Kamala Das as a Confessional Poet”. In C. Kulshrestha (Ed.), Contemporary Indian English Verse (pp. 201-207). New delhi: Arnold Heinemann.

Raveendran, N.V. (200o). The Aesthetics of Sensuality: A Stylistic Study of the Poetry of Kamala Das. New Delhi: Atlantic.

Satchidanandan, K. (1999). Transcending the Body. In K. Das (Author), Only the Soul Knows How to Sing (pp. 9-18). Kottayam: DC Books. 
---. (2009). Relocating My Story. In K. Das (Author), My Story (pp. vii-xviii). New York: Harper Collins.

Shukla, D. K. (2010). Poetry of Kamala Das: The Aesthetic Dimension. New Delhi: Adhyayan Publishers \& Distributors.

Weisbord, M. (2010). The Love Queen of Malabar: Memoir of a Friendship with Kamala Das. London: McGill-Queen's University Press.

Zimmerman, B. (1985). "What Has Never Been: An Overview of Lesbian Feminist Literary Criticism." In E. Showalter (Ed.), Feminist Criticism: Essays on Women, Literature, Theory (pp. 200-219). New York: Pantheon Books.

Sandhya V is Assistant Professor at the department of English and Humanities, Amrita Vishwa Vidya peetham, Coimbatore. She is pursuing her $\mathrm{PhD}$ in gender studies.

Hari M G is Assistant Professor in the Department of English and Humanities, Amrita Vishwa Vidyapeetham, Coimbatore. He holds a PhD in English Literature from IIT Kharagpur. He is a recipient of research fellowships such as UGC-JRF, and Institute Fellowship, IIT Kharagpur. His areas of research include Bhakti Poetry, Indian English Poetry, Bhasha Literatures, and Literary Theory.

Dr.Harini Jayaraman is Professor and Chair at the department of English, Amrita Vishwa Vidyapeetham, Coimbatore. Her areas of interest include Indian Literature, Comparative Literature and English Language Teaching. 